\title{
GŁÓWNE KIERUNKI DZIAŁALNOŚCI LIGI KOBIET W POLSCE LUDOWEJ DO 1975 ROKU (ZE SZCZEGÓLNYM UWZGLĘDNIENIEM WOJEWÓDZTWA BIAŁOSTOCKIEGO)
}

\author{
Małgorzata Dajnowicz
}

Uniwersytet w Białymstoku

\author{
ABSTRACT \\ THE MAIN AREAS OF THE ACTIVITIES OF WOMEN'S LEAGUE IN \\ POLISH PEOPLE'S REPUBLIC UNTIL 1975 (WITH SPECIAL REGARD \\ TO BIAŁYSTOK VOIVODESHIP)
}

Women's League (till 1949 known under the name of the Social and Civic League of Women) was a large-scale women's organization in Polish People's Republic. Through the whole period of its existence, the organization's priority was to build up the mass character of the League and expand its services to reach women from different walks of life, which corresponded with the general policy of the country aiming at implementing the so-called communist order. The members of Women's League were at the same time members of the Polish United Workers' Party. The League, apart from being a very effective propaganda tool, tried to play a real supportive role offering women practical help. However, it seems that although the organization focused on expanding the range of its services and attracting a growing number of members, it didn't achieve the expected results.

Keywords: Women's League, women's organization, communist system, Polish United Workers' Party, Polish People's Republic, Białystok Voivodeship.

Słowa kluczowe: Liga Kobiet, organizacja kobieca, system komunistyczny, KC PZPR, Polska Ludowa, województwo białostockie.

\section{UWAGI WSTĘPNE}

Liga Kobiet (LK) w okresie od 1945 do 1975 roku występowała pod dwoma nazwami: do 1949 roku jako Społeczno-Obywatelska Liga Kobiet (SOLK) i następnie 
od 1949 roku jako LK ${ }^{1}$. Aktywność LK, masowej organizacji kobiecej związanej z systemem komunistycznym Polski Ludowej, była tematyką prezentowaną w niewielkim stopniu w dotychczasowych ustaleniach naukowych. Badania nad aktywnością organizacyjną LK prowadziła Barbara Nowak, a ich wyniki zawarła w pracy doktorskiej, napisanej w Stanach Zjednoczonych ${ }^{2}$. Ustalenia badawcze B. Nowak wymagają jednak poważnych uzupełnień, których można byłoby dokonać na bazie głębszej kwerendy archiwalnych materiałów źródłowych, przechowywanych zwłaszcza w Warszawie. Na oddzielną wnikliwą kwerendę zasługują archiwalia, nieanalizowane przez B. Nowak, znajdujące się w wojewódzkich archiwach państwowych, materiały dotyczące działalności Ligi na obszarze poszczególnych regionów, okręgów, powiatów, miast i osiedli. Należy również podkreślić, że nieocenionym materiałem, dostarczającym szerokiej bazy źródłowej do opisu różnych obszarów aktywności Ligi pozostaje wciąż słabo analizowany i wykorzystywany w opracowywaniu LK materiał prasowy periodyków wydawanych przez tę organizację ${ }^{3}$.

Wśród polskich badaczy zajmujących się opisem rzeczywistości społecznej okresu po 1945 roku działalność Ligi Kobiet nie budziła poważnych zainteresowań naukowych. Na wyróżnienie zasługuje zwłaszcza artykuł Dariusza Jarosza, wnoszący dość istotne ustalenia poznawcze na temat funkcjonowania Ligi Kobiet w latach $1945-1957^{4}$.

Problematyka dotycząca działalności LK na tle rzeczywistości społecznej i politycznej PRL, aktywność organizacyjna oraz zasięg oddziaływania Ligi Kobiet w polskich środowiskach kobiecych nadal wymagają badań szczegółowych. Na podstawie analizy materiałów źródłowych, a także opracowań zasobów prasy związanej $\mathrm{z}$ organizacją ${ }^{5}$ autorka opracowania ustaliła zróżnicowaną działalność organiza-

1 W 1982 r. Liga Kobiet zmieniała nazwę na Ligę Kobiet Polskich.

2 B. Nowak, Serving Women and the State: The League of Women in Communist Poland, praca doktorska, The Ohio State University 2004 [dostęp: 7.04.2017]. Dostępny w World Wide Web: http://bit.ly/2diMB3h.

3 Wskazać należy przede wszystkim na „Naszą Pracę” (1947-1989), wykorzystywaną wybiórczo przez Barbarę Nowak, oraz „Zwierciadło” (1957-1961 i 1982-1989, wydawane przez Ligę Kobiet), które nie było dotychczas wykorzystywane pod względem przydatności dla opracowania Ligi Kobiet. Autorka artykułu jako pierwsza analizowała pod tym kątem niniejszy periodyk kobiecy - M. Dajnowicz, ,Zwierciadto” platforma polityczna Ligi Kobiet w okresie PRL (1957-1961, 1982-1989), „Rocznik Historii Prasy Polskiej” 2017, t. 20, z. 3(47), s. 67-90.

4 D. Jarosz, Idee, programy i realia: funkcje Ligi Kobiet w porzadku instytucjonalnym Polski Ludowej (1945-1957) [w:] Działaczki społeczne, feministki, obywatelki. Samoorganizowanie się kobiet na ziemiach polskich po 1918 roku (na tle porównawczym), t. II, red. A. Janiak-Jasińska, K. Sierakowska, A. Szwarc, Warszawa 2009, s. 307-330. Artykuły przyczynkarskie na temat Ligi Kobiet i jej działalności lokalnej napisali: N. Jarska, Liga Kobiet w terenie. Działalność Zarzadu Dzielnicowego Poznań-Wilda 1956-1966 [w:] Letnia Szkoła Historii Najnowszej 2009. Referaty, red. Ł. Kamiński, T. Kozłowski, Warszawa 2010, s. 149-158; N. Lubik-Reczek, R. Reczek, Liga Kobiet-organizacja „reprezentujaca” interesy kobiet w Polsce Ludowej. Zarys działania, „Środkowoeuropejskie Studia Polityczne" 2013, nr 4, s. 105-120; M. Dajnowic z, Obchody Międzynarodowego Roku Kobiet 1975 na Białostocczyźnie (na tle głównych kierunków działalności Ligi Kobiet w kraju i regionie), „Czasopismo Naukowe Instytutu Studiów Kobiecych" 2017, nr 1 (2), s. 9-27.

Poza opracowaniem „Zwierciadła” autorka artykułu analizowała „Naszą Pracę” z pierwszych lat wydawania biuletynu - M. Dajnowicz, Działalność Społeczno-Obywatelskiej Ligi Kobiet w świetle 
cji w poszczególnych okresach jej funkcjonowania. Celem artykułu jest ukazanie podstawowych kierunków działalności organizacji w kraju, ze szczególnym uwzględnieniem rozwoju Ligi w województwie białostockim, w okresie trzydziestolecia jej funkcjonowania. Rok 1975 ogłoszono nie tylko Międzynarodowym Rokiem Kobiet - między innymi w nawiązaniu do obchodów przeprowadzano wówczas wieloobszarowe podsumowania dokonań i porażek w rozwoju Ligi Kobiet w latach 1945-1975.

\section{SPOŁECZNO-OBYWATELSKA LIGA KOBIET}

SOLK powstała w sierpniu 1945 roku i poprzez nazwę nawiązywać miała do organizacji patriotyczno-niepodległościowej z okresu przed rokiem 1914. W pierwszych latach działalności Ligi prace prowadzone były bez wyraźnych wytycznych, programu i statutu. Miała być to organizacja wielonurtowa i masowa oraz zarazem dostosowana do potrzeb nowej rzeczywistości Polski powojennej ${ }^{6}$. W statucie SOLK z 1947 roku cele stowarzyszenia określono bardzo ogólnie, podając, że Liga będzie walczyć „o stały i sprawiedliwy pokój na świecie, oparty na zasadach demokratycznych”, bronić „,praw i interesów kobiety” oraz „rodziny ze szczególnym uwzględnieniem interesów dziecka”. Celem Ligi miało być także „wychowanie kobiety, obywatelki, świadomej swych praw i obowiązków w stosunku do Ojczyzny i społeczeństwa” oraz „,czynny jej udział w pracy państwa i w jego odbudowie" . W statucie organizacji podano Warszawę jako siedzibę władz centralnych, w opisie struktury organizacyjnej wskazywano na możliwość powoływania kół wojewódzkich i im podległych kół powiatowych oraz miejskich. Pracami kół kierować miały zarządy miejskie i powiatowe, podległe zarządom wojewódzkim, które z kolei podlegać miały głównemu zarządowi ${ }^{8}$. W ramach działalności Zarządu Głównego funkcjonowało dziewięć wydziałów: organizacyjny, finansowy, oświatowo-wychowawczy, prasowo-wydawniczy, gospodarczy, zdrowia i opieki, zagraniczny, prawny, młodzieżowy i wychowania fizycznego ${ }^{9}$. Zarząd Główny miał opracowywać plany działania organizacji na podstawie informacji otrzymywanych od zarządów wojewódzkich ${ }^{10}$. W deklaracji ideowej SOLK informowano odbiorców o konieczności włączenia kobiet polskich w prace nad „odbudową Ojczyzny”, ,utrwaleniem pokoju

„Naszej Pracy” (1947-1949) [w:] Polityka i politycy w prasie XX i XXI wieku, pod red. M. Dajnowicz i A. Miodowskiego, Białystok 2016, s. 295-307.

6 Zob. D. Jaros z, op. cit., s. 308.

7 Statut Spoleczno-Obywatelskiej Ligi Kobiet, [Warszawa], b.r.w., s. 4.

8 Ibidem, s. 7-8.

9 Archiwum Akt Nowych (dalej: AAN), Społeczno-Obywatelska Liga Kobiet. Zarząd Główny w Warszawie 1945-1948 (dalej: SOLK),1, Zakres działania Wydziałów Zarządu Głównego Społeczno-Obywatelskiej Ligi Kobiet, k. 12 i nast.

10 AAN, SOLK, 1, Regulamin dla Zarządu Głównego Społeczno-Obywatelskiej Ligi Kobiet, k. 11. 
i demokracji w Polsce”, w starania „, faktyczne równouprawnienie kobiet” i „o lepsze i piękniejsze życie rodzinne"11.

W sprawozdaniu pod tytułem Rozwój Ligi Kobiet w okresie od 1945 do 1951 roku podano, że nadrzędnym celem określonym przez Zarząd Główny było „zbudowanie masowego, demokratycznego ruchu kobiecego w Polsce, opartego na szerokiej rekrutacji kobiet ze wszystkich warstw społecznych" "2. Jeszcze w 1945 roku zdecydowano o powołaniu zarządów wojewódzkich w Łodzi, Warszawie, Krakowie, Gdańsku, Poznaniu, Katowicach, Bydgoszczy i Białymstoku. W 1946 roku zorganizowano struktury SOLK w kolejnych województwach - we Wrocławiu, Szczecinie, Rzeszowie, Olsztynie, Kielcach i Lublinie ${ }^{13}$.

Polem działań organizacji oprócz działalności opiekuńczej, higieniczno-sanitarnej, kulturalno-oświatowej, szkolenia zawodowego dla kobiet i w zakresie usprawniania gospodarstwa domowego było również tworzenie spółdzielni (np. szwalni, piekarni czy pralni), które miałyby „nieść pomoc w prowadzeniu gospodarstw domowych” oraz pełnić zadania ideowe w zakresie „uświadomienia spółdzielczego kobiet poprzez odczyty, pogadanki, radio, prasę, wydawnictwa". Zachęcano również kobiety niezrzeszone w SOLK do członkostwa w tego rodzaju spółdzielniach ${ }^{14}$. Od pierwszych miesięcy funkcjonowania Liga dosyć intensywnie zaczęła włączać się również w szerokie akcje polityczno-propagandowe, mające charakter „wsparcia" dla zachodzących zmian politycznych w Polsce po zakończeniu II wojny światowej. Okazją do tego rodzaju działań był udział członkiń organizacji w obchodach świąt państwowych, takich jak 1 maja czy 8 marca. Zwłaszcza w Międzynarodowym Dniu Kobiet, 8 marca, w miastach i zakładach pracy odbywały się uroczyste akademie i zebrania, podczas których delegowane przez Ligę aktywistki wygłaszały referaty i pogadanki, przykładowo o tytułach Kobieta w walce o pokój, Cele i zadania Ligi Kobiet, 8 marca - Międzynarodowy Dzień Kobiet ${ }^{15}$.

Do aktywnych oddziałów wojewódzkich SOLK należał bez wątpienia katowicki, w którym funkcjonowała między innymi poradnia prawna dla kobiet, prężnie działająca sekcja zajmująca się opieką nad matką i dzieckiem, sekcja oświatowo-wychowawcza ${ }^{16}$. W sprawozdaniach dotyczących aktywności organizacji w latach 1945-1946 wymienia się także oddziały łódzki i gdański (w drugim z wymienionych funkcjonowało w 1946 roku 13 kół powiatowych) ${ }^{17}$. Na oddzielne podkreślenie

11 AAN, SOLK, 1, Deklaracja ideowa Spoleczno-Obywatelskiej Ligi Kobiet, k. 8-10.

12 AAN, Polska Zjednoczona Partia Robotnicza, Komitet Centralny (dalej: PZPR, KC), Wydział Kobiecy (dalej: WK KW), 237/XV-30, Rozwój Ligi Kobiet w okresie od 1945-1951 r., k. 1.

13 Ibidem, k. 1-3.

14 AAN, SOLK, 1, Zadania Wydziału Spółdzielczego w Kole Społeczno-Obywatelskiej Ligi Kobiet, k. 17, 20 i nast.

15 Archiwum Instytutu Pamięci Narodowej (dalej: AIPN), BU 01760/350, Materialy dotyczace Zarzadu Ligi Kobiet przy MBP. Protokoty z zebrań, sprawozdania, notatki 1946-53, Protokót Ogólnego Zebrania Ligi Kobiet M. B. P. w dniu 7 maja 1947 r., k. 4.

16 AAN, SOLK, 1, S.O.L.K. w Katowicach. Poradnia prawna, k. 31, S.O.L.K. w Katowicach. Instrukcje organizacyjne, k. 32.

17 AAN, SOLK, 1, k. 41; 2, Protokót z posiedzenia Wydziału Spótdzielczego Społeczno-Obywatelskiej Ligi Kobiet, k. 9 i nast.; 4, Sprawozdanie z działalności Wydziału Organizacyjnego i Wydziału Spót- 
zasługiwało koło SOLK działające przy Krajowej Radzie Narodowej, które w końcu 1946 roku liczyło około 300 członkińn $^{18}$.

SOLK w województwie białostockim powołana została w marcu 1946 roku, o czym informował okólnik Komitetu Centralnego Polskiej Partii Robotniczej dotyczący pracy wśród kobiet przed referendum z 30 czerwca 1946 roku $^{19}$. Według ustaleń Izabeli Ratman-Liwerskiej pierwsze koła Ligi na tym terenie powstały już w sierpniu 1945 roku, inicjowane przez Edwardę Orłowską ${ }^{20}$, ówczesną sekretarz Komitetu Wojewódzkiego PPR, następnie wiceprzewodniczącą wojewódzkiego zarządu SOLK w Białymstoku. W 1946 roku istnieć już miały zarządy powiatowe Ligi, podległe Zarządowi Wojewódzkiemu w Białymstoku. Podczas referendum w 1946 roku członkinie SOLK $\mathrm{z}$ terenu województwa zorganizowane w grupach zajmowały się rozpowszechnianiem ulotek propagujących udział $\mathrm{w}$ referendum i instruujących „jak należy głosować”. Poza tym członkinie Ligi brały udział w przygotowywaniu lokali komisji obwodowych do głosowania. Również przed wyborami do Sejmu Ustawodawczego w styczniu 1947 roku Wydział Kobiecy KW PPR w Białymstoku zwoływał narady aktywu kobiecego z udziałem członkiń Zarządu Wojewódzkiego SOLK, między innymi w celu omówienia obowiązków członkiń organizacji związanych z udziałem w nadchodzących wyborach. Przed wyborami kobiety zrzeszone w SOLK weszły w skład kilkunastoosobowego zespołu Wojewódzkiego Koła Prelegentek Przedwyborczych, odpowiedzialnego za pracę propagandową wśród kobiet $\mathrm{w}$ okresie przedwyborczym. Jedną z najbardziej wówczas zaangażowanych w akcję propagandową była Zofia Brzozowska, członkini zarządu wojewódzkich struktur SOLK, która przekonywała również kobiety z województwa, że Liga, choć miała być apolityczna, winna być organizacją „o jasno określonych poglądach politycznych, tożsamych ze światopoglądem PPR”21. Pod koniec 1947 roku przy Zarządzie Wojewódzkim SOLK w Białymstoku funkcjonowały cztery wydziały: organizacyjny, opieki społecznej, spółdzielczy i kulturalno-oświatowy ${ }^{22}$. Ważnym polem aktywności również na poziomie kół powiatowych SOLK była pomoc dzieciom - w jej ramach zakładano ochronki dla dzieci, przedszkola i żłobki. Innym równie istotnym

dzielczego w Zarządzie Wojewódzkim Spoteczno-Obywatelskiej Ligi Kobiet na województwo gdańskie, k. 1-17, 26, 38; 5, Plan pracy Wydzialu Spółdzielczego Wojewódzkiego Zarządu S.O.L.K. w Gdańsku za m-c sierpień $1947, \mathrm{k} .3$.

18 AAN, SOLK, 3, Sprawozdanie z działalności Społeczno-Obywatelskiej Ligi Kobiet Koła przy Biurze Prezydialnym K. R. N., k. 1 i nast.

${ }^{19}$ A. Stasiewicz, Działalność Społeczno-Obywatelskiej Ligi Kobiet w latach 1945-1948 na Białostocczyźnie w świetle dokumentów PPR [w:] Kobiety na zakręcie 1933-1989, red. E. Chabros, A. Klarman, Wrocław 2014, s. 54.

20 Edwarda Orłowska, komunistka urodzona w Białymstoku, w latach 1946-1948 kierowała Wydziałem Kobiecym PPR, a po zjednoczeniu z PPS i powstaniu PZPR analogiczną komórką przy KC PZPR do $1953 \mathrm{r}$.

${ }_{21}$ Archiwum Państwowe w Białymstoku (dalej: APB), Komitet Wojewódzki Polskiej Partii Robotniczej (dalej: KW PPR), 229, Sprawozdanie z II pracy Zarzadu SOLK za okres od do 30 IX 1946 r, k. 13 i nast.

22 APB, KW PPR, Sprawozdanie Zarządu Wojewódzkiego SOLK w Biatymstoku za miesiąc grudzień 1947, k. 25. 
zadaniem członkiń organizacji, poza szeroko rozumianą pracą propagandową, było organizowanie kursów zawodowych dla kobiet. Obejmowały one szkolenia w zakresie przygotowania do pracy w szwalniach, pralniach, w tym w tworzonych przez SOLK spółdzielniach. W 1948 roku Zarząd Wojewódzki białostockiej SOLK zorganizował sześć kursów zawodowych dla kobiet z terenu województwa. Każdy trwał trzy miesiące, uczestniczyło w nich po 30 słuchaczek $^{23}$.

Na łamach „Naszej Pracy” publikowano sprawozdania zatytułowane Liga Kobiet $w$ terenie. $\mathrm{W}$ jednym $\mathrm{z}$ nich odnotowano, że $\mathrm{w}$ Białymstoku kilkadziesiąt członkiń organizacji ukończyło kursy kroju i mody, tworzone przy wsparciu organizacyjnym kuratorium oświaty. Ponadto członkinie Ligi „,brały udział w akcji pomocy zimowej, pomocy powodzianom, oraz współpracowały w podjętej przez kuratorium akcji organizowania dla dzieci kolonii i półkolonii”24. Z kolei w 1948 roku „przy zarządzie wojewódzkim w Białymstoku utworzono Komisję Społeczno-Obyczajową. Komisja ta współpracowała z Komisją Sanitarno-Obyczajową Milicji Obywatelskiej, której zadaniem była walka z nierządem wśród kobiet oraz z żebractwem i przestępczością wśród nieletnich dzieci”" ${ }^{25}$. W sprawozdaniu z działalności SOLK w województwie białostockim zamieszczono informację, że w 1949 roku wydział kulturalno-oświatowy SOLK zorganizował czterodniowy kurs dla prelegentek, które z kolei zorganizowały pięć kursów powiatowych z udziałem 212 członkiń organizacji. Przeszkolone podczas tych kursów, pod auspicjami SOLK, zorganizowały 49 kursów dla analfabetek oraz 45 zespołów czytelniczych, podczas których upowszechniano wśród kobiet czytanie książek ${ }^{26}$.

Można wnioskować, że do 1947 roku dominującymi obszarami aktywności organizacji były działania na rzecz opieki nad matką i dzieckiem oraz szkolenia zawodowe dla kobiet. Ważne miejsce w rozwoju SOLK zajmowały akcje propagandowo-wychowawczo-oświatowe i kursy dla analfabetek. Wszystkie inicjatywy prowadzić miały do zwiększenia liczebności członkiń reprezentujących różne środowiska zawodowe oraz kobiety niepracujące ${ }^{27}$. Według oficjalnych danych w 1947 roku liczba kobiet zrzeszonych w SOLK - skupionych w 4000 kołach - miała wynosić 693 tysiące $^{28}$. Z kolei według sprawozdań Wojewódzkiego Zarządu SOLK w Białymstoku liczba kobiet zrzeszonych w organizacji w końcu 1946 roku wynosiła 4500 członkińn ${ }^{29}$, natomiast w początkach 1949 roku - już 11500 kobiet zrzeszonych w 269 kołach $^{30}$.

${ }^{23}$ APB, KW PPR, Sprawozdanie Wydziału Kobiecego KW PPR w Bialymstoku za okres od marca do września 1948 r., k. 104.

24 Liga Kobiet przy pracy, „Nasza Praca” 1947, nr 3-4, s. 23-25.

25 Ibidem, 1948, nr 1, s. 18.

26 AAN, PZPR, KC, Wydział Kobiecy - KW Białystok (dalej: WK KWB), 237/XV-9, Sprawozdanie Wydziału Kobiecego K.W. P.Z.P.R. w Bialymstoku za m-c kwiecien 1949 r., k. 30-31.

27 Zob. szerzej M. Dajnowicz, Działalność Społeczno-Obywatelskiej Ligi Kobiet..., s. 295-307.

${ }^{28}$ AAN, PZPR, KC, KW, 237/XV-30, Rozwój Ligi Kobiet w okresie od 1945-1951 r., k. 3.

29 A. Stasiewicz, op. cit., s. 57.

30 AAN, PZPR, KC, KWB, 237/XV-9, Sprawozdanie Wydziału Kobiecego przy K.W. PZPR w Białymstoku za miesiac luty 1949 r., k. 22. 


\section{LIGA KOBIET I JEJ DZIAŁALNOŚĆ DO POŁOWY LAT PIĘĆDZIESIĄTYCH}

We wrześniu 1949 roku zmieniono nazwę z SOLK na Ligę Kobiet ${ }^{31}$. LK miała podjąć intensywniejszą niż wcześniej pracę wychowawczą i propagandową w różnych środowiskach kobiecych. W związku z tym w skład Zarządu Głównego włączono przedstawicielki związków zawodowych, Związku Samopomocy Chłopskiej, Rodzin Wojskowych, organizacji młodzieżowych i społecznych oraz spółdzielni. Ponadto w wytycznych PZPR znalazły się instrukcje dotyczące wspólnych działań Ligi i ZSCh wśród kobiet wiejskich, omawiające między innymi organizację przebiegu uroczystości świąt pierwszomajowych ${ }^{32}$. W 1949 roku organizacja liczyć miała już 1,5 miliona członkiń skupionych w 30 tysiącach kół. W programie działań Ligi wśród kobiet znalazły się między innymi kursy dla kierowniczek świetlic i zespołów czytelniczych oraz opiekunek społecznych. „W 1950 roku praca Ligi wkracza na tory wybitnie społeczno-polityczne. Liga Kobiet pracuje planowo, włącza się do Ogólnoplanowej Gospodarki Państwowej" - podkreślano w sprawozdaniu dotyczącym rozwoju $\mathrm{LK}^{33}$. W 1950 roku postanowiono o reorganizacji wydziałów, uzasadniając to dostosowaniem Ligi do istniejących potrzeb społecznych. W strukturach organizacji powstały wcześniej niefunkcjonujące działy szkolenia ideologicznego, aktywizacji kobiet w nowych zawodach oraz propagandy i pracy. Postanowiono również o podjęciu intensywnego szkolenia młodych kobiet jako przyszłych kadr organizacji ${ }^{34}$.

W województwie białostockim w 1949 roku w skład trzynastoosobowego Wojewódzkiego Wydziału Kobiecego PZPR wchodziły dwie liderki LK: Berta Szaykowska, przewodnicząca ZW LK, i Zofia Dachłowa, sekretarz zarządu Wojewódzkiego $\mathrm{LK}^{35}$. Na obszarze województwa liczba członkiń, pracujących w 1208 kołach, wynosić miała wówczas ponad 32 tysiące. W skład zarządu wchodziło 20 kobiet, poza wyżej wymienionymi były to między innymi Janina Szulewska, kierownik organizacyjna ZW LK, Jadwiga Mickiewicz, sekretarz odpowiedzialna Zarządu Miejskiego LK, czy Jadwiga Zubrycka, przewodnicząca Miejskiej Rady Narodowej w Białymstoku. Znaczącą większość członkiń zarządu stanowiły nauczycielki przynależne do struktur PZPR ${ }^{36}$.

W 1950 roku na terenie województwa białostockiego funkcjonować miało 12 zarządów powiatowych ${ }^{37}$. Należy dodać, że według danych Zarządu Głównego LK organizacja liczyła w końcu 1950 roku 1713860 członkiń zorganizowanych w ponad

31 Pod tą nazwą organizacja funkcjonowała od 9 IX 1949 r. do 2 XII 1982 r. Od 1982 r. zmieniono nazwę na Ligę Kobiet Polskich - Dz.U. 1982 Nr 38, poz. 254.

32 AAN, PZPR, KC, KW, 237/XV-29, Instrukcja w sprawie obchodu 1-ego maja, k. 35.

33 AAN, PZPR, KC, WK KW, 237/XV-30, Rozwój Ligi Kobiet w okresie od 1945-1951 r., k. 4.

34 Ibidem, k. 5.

35 AAN, PZPR, KC, WK KWB, 237/XV-9, Sprawozdanie Wydziału Kobiecego Komitetu Wojewódzkiego P.Z.P.R. w Biatymstoku za m-c wrzesień 1949 r., k. 45.

36 Ibidem, k. 46 - Kobiety stanowić miały $11 \%$ członków PZPR.

37 I. Ratman-Liwerska, Stowarzyszenie jako czynnik społeczno-wychowawczej aktywizacji kobiet (na przyktadzie badań na Białostocczyźnie), Białystok 1984, s. 119. 
38653 kołach, z czego 823678 członkiń zrzeszono w 10929 kołach w zakładach pracy; 315146 - w 3384 terenowych kołach miejskich; 503044 - w 21699 kołach gospodyń wiejskich; 50749 - w 2300 kołach Państwowych Gospodarstw Rolnych i 21443 członkiń - w 341 kołach rodzin wojskowych ${ }^{38}$.

Po 1950 roku duży nacisk LK położyła na tworzenie kół terenowych, zwanych blokowymi, a także budowania sieci placówek w zakładach pracy, na wsi (w Państwowych Gospodarstwach Rolnych) oraz w mieście, także wśród gospodyń domowych. Zarząd Główny LK zgodnie z wydaną instrukcją dotyczącą pracy organizacji wśród kobiet w miejscu ich zamieszkania zalecał „powiązanie kół terenowych LK z pracą Komitetów Blokowych, miejscowych Komitetów Obrońców Pokoju, Komisji Rad Narodowych oraz włączenie do prac Komitetów Rodzicielskich, sklepowych, komitetów do walki z alkoholizmem" ${ }^{39}$. W celu popularyzacji działalności kół terenowych zamieszczono na łamach „Przyjaciółki” cykl artykułów, w których opisywano konkretne przykłady aktywności tego rodzaju placówek. Ponadto zakładano wzmocnienie roli związków zawodowych w zakresie prac wśród kobiet oraz przeprowadzenie wyborów do Rad Kobiecych we wszystkich zakładach pracy zatrudniających powyżej 20 kobiet, ściślejszą niż dotychczas współpracę z aktywem partyjnym PZPR i włączenie do prac organizacyjnych LK robotnic i chłopek. Równocześnie w Zarządzie Głównym LK dokonano podziału na sekcje: aktywizacji zawodowej i spraw socjalno-bytowych, wiejską, agitacji indywidulanej i grupowej, kulturalno-oświatową ${ }^{40}$. Ważną rolę w pracy organizacyjnej Ligi odgrywało inicjowanie aktywności kobiecej na wsi. W sprawozdaniu za I kwartał 1951 roku, obejmującym analizę działalności organizacyjnej LK w 10 województwach Polski, wskazywano, że w porównaniu ze stanem za poprzedni kwartał sprawozdawczy zmniejszyła się liczba kół blokowych w mieście, zaś na wsi przybyło 277 kół gospodyń wiejskich oraz 818 kół Ligi, powołanych w Państwowych Gospodarstwach Rolnych ${ }^{41}$.

W 1951 roku na I kongresie LK, gdzie na przewodniczącą Zarządu Głównego, po Irenie Sztachelskiej, wybrano Alicję Musiałową, uchwalono nowy statut, w którym podkreślono między innymi konieczność włączenia szerokich rzesz kobiecych, w tym robotnic, kobiet wiejskich, inteligentek, ale również i gospodyń domowych, do ważnych zadań, takich jak prace nad „budową socjalistycznej potęgi gospodarczej" czy dążenia do zapewnienia równouprawnienia kobiet z mężczyznami we wszystkich dziedzinach życia państwowego, społecznego i gospodarczego. W statucie umieszczono również zapisy dotyczące opieki organizacji nad matką i dzieckiem oraz dbałości o podnoszenie poziomu świadomości, oświaty i kultury najszerszych rzesz kobiet ${ }^{42}$.

W sprawozdaniach politycznych Wydziału Kobiecego PZPR kierowanego przez Edwardę Orłowską opisywano zakres aktywności poszczególnych oddziałów LK

38 Cyt. za: D. Jarosz, op. cit., s. 320.

39 AAN, PZPR, KC, WK KW, 237/XV-30, Sprawozdanie z działalności Ligi Kobiet za IV kwartał, 1951 r., k. 49.

40 AAN, PZPR, KC, WK KW, 237/XV-30, Osiagnięcia i braki, k. 75-78.

41 Ibidem, k. 79.

42 D. Jarosz, op. cit., s. 316-317. 
$\mathrm{z}$ terenu kraju. Mimo szeroko zakrojonych prac propagandowo-wychowawczych uświadamiających kobiety, informowała przewodnicząca WK Edwarda Orłowska, w 1951 roku notowano słabe zainteresowanie aktywnością LK i kół gospodyń wiejskich w województwie lubelskim, poznańskim i rzeszowskim ${ }^{43}$. LK, podporząakowana PZPR w sferze ideologii, realizacji programu politycznego i sposobów działania $\mathrm{w}$ środowiskach kobiecych, $\mathrm{z}$ jednej strony eksponowała swoje sukcesy, między innymi poprzez sprawozdania o zasięgu odziaływania i zwiększającej się liczebności kół i członkiń, z drugiej zaś strony w sprawozdaniach zamieszczała informacje o niedostatecznym zaangażowaniu aktywistek, braku zainteresowania pracą ligową, zwłaszcza kobiet niepracujących, także kobiet wiejskich i przede wszystkim młodych kobiet. Przykładowo przeprowadzona kontrola ZG LK w województwie lubelskim wykazała, że niewłaściwy styl pracy ZW LK w Lublinie spowodował również

słabą pracę Zarządów Powiatowych LK, które w dalszym ciągu nie prowadzą planowej pracy jako zespół kierowniczy organizacji. Brak planowej, systematycznej pracy zarządów, podziału pracy i odpowiedzialności pomiędzy poszczególne członkinie Zarządu, brak właściwie pracujących sekcji powoduje niedostateczne włączenie do pracy aktywu społecznego i zmniejsza poważnie możliwości jego rozwoju.

Ponadto dodano w podsumowaniu, że

praca zarządów ZSCh i LK była niedostateczna, a zły jej styl przejawiał się w braku koordynacji pracy, braku planów pracy, w niedostatecznym kierowaniu i w braku opieki nad gminnymi radami kobiecymi i kołami gospodyń Związku Samopomocy Chłopskiej ${ }^{44}$.

Pozytywnie natomiast w tym czasie oceniono rozwój LK w powiecie suwalskim województwa białostockiego. Stwierdzono w wyniku kontroli, że

Zarząd Powiatowy LK kładzie słuszny nacisk na rozbudowę sieci kół terenowych. W chwili obecnej w Suwałkach istnieje 14 kół terenowych, które obejmują 450 członkiń. Zarządy kół terenowych są żywotne, pracują według swoich planów i mają konkretne przydzielone zadania. Ciekawe są formy pracy przodownic społecznych, których w mieście Suwałki jest 50. Należy również podkreślić pracę Prezydium Zarządu Powiatowego LK, którego niewątpliwą zasługą jest umiejętność dobrania i wychowania aktywu kobiecego dzięki czemu pracę organizacji na terenie Suwałk można określić jako dobrą ${ }^{45}$.

Także kontrola funkcjonujących w 1951 roku zakładanych przez LK świetlic zarówno w Suwałkach, jak i Białymstoku przedstawiała się pozytywnie ${ }^{46}$. Natomiast w Uchwale Egzekutywy KW PZPR w Białymstoku z grudnia 1951 roku stwierdzono, że „masowo-polityczna praca wśród kobiet, robotnic, chłopek, gospodyń domowych jest niedostateczna. W związku z tym zaleca się rozszerzenie pracy uświadamiającej $\mathrm{w}$ środowiskach będących poza zasięgiem organizacyjnym LK, to jest wśród gospodyń domowych poprzez indywidualną agitację w domach. Szczególne

43 AAN, PZPR, KC, WK, 237/XV-7, Sprawozdanie Orlowskiej Edwardy, k. 9-11.

44 Praca wśród kobiet wiejskich woj. lubelskiego, „Nasza Praca” 1951, nr 13-14, s. 20.

45 M. Wawrykowa, Wnioski i uwagi z wizytacji z terenu. Jeszcze raz o Suwatkach, „Nasza Praca” 1951 , nr 15, s. 32-33.

46 A. Golsztyńska, Analiza pracy świetlic, „Nasza Praca” 1951, nr 20, s. 46. 
zaangażowanie LK powinna poświęcić pracy w spółdzielniach produkcyjnych" ${ }^{47}$. W celu dalszego rozwoju LK w województwie białostockim organizowano kursy i konferencje, podczas których przekonywano słuchaczki do tworzenia nowych kół terenowych i zakładowych. Ponadto powoływano placówki do walki z analfabetyzmem, tworzono zespoły czytelnicze w kołach i świetlicach, organizowano dziecińce wiejskie, pokazy zdrowego żywienia. Pod auspicjami LK organizowano tzw. współzawodnictwo pracy. Okazją do upowszechniania znaczenia LK w środowiskach kobiecych było również włączanie się organizacji w obchody pierwszomajowe i z tej okazji organizowanie „wieczorów 1-majowych” dla kobiet w świetlicach LK. Liga inicjowała także udział kobiet wiejskich w pochodach pierwszomajowych odbywających się w miastach województwa białostockiego ${ }^{48}$.

W I połowie 1952 roku LK włączyła się w ogólnonarodową dyskusję nad projektem konstytucji PRL. W zarządach wojewódzkich organizowano specjalne seminaria, podczas których aktyw LK zapoznawał się z treścią proponowanej konstytucji i przygotowywał do pracy agitacyjnej. Zarządy Wojewódzkie organizowały na obszarze swojej działalności punkty agitacyjne, w których na temat konstytucji wykłady wygłaszały aktywistki LK. Uwagę zwracała aktywność członkiń kół terenowych. Przykładowo:

w Białymstoku jedno z kół terenowych wezwało wszystkie koła LK na terenie całego województwa do doprowadzenia treści Konstytucji do każdej kobiety zamieszkałej na ich terenie, bądź też przez indywidualną agitację. Wezwanie to ukazało się w prasie miejscowej i zostało ogłoszone przez radiowęzeł, dzięki czemu doszło do wszystkich zakątków województwa, zostało gorąco przyjęte i dało dobre wyniki ${ }^{49}$.

Po 1950 roku w sposób szczególny upowszechniano znaczenie aktywności zawodowej kobiet, promowano zwłaszcza zatrudnienie kobiet w produkcji. Alicja Musiałowa, przewodnicząca ZG LK w referacie zawierającym podsumowanie okresu działalności Ligi za lata 1945-1955, podkreślała, że działalność organizacji „która na I Ogólnopolskim Kongresie Ligi Kobiet w marcu 1951 roku postawiła sobie za zadanie włączenie kobiet do produkcji i pracy we wszystkich zawodach przyczyniła się poważnie do tych osiągnięć" "50. W 1953 roku zlikwidowano Wydziały Kobiece w strukturach KC PZPR i w ich miejsce powołano Wydziały Organizacyjne, które miały koordynować prace $\mathrm{w}$ środowiskach kobiecych. W tym też roku zlikwidowano koła zakładowe LK, w związku z czym organizacja miała za zadanie inicjowanie większego niż wcześniej zaangażowania związków zawodowych w sprawy kobiet pracujących, które potrzebowały wsparcia - jak podawała A. Musiałowa - „w zakresie ich aktywizacji zawodowej i edukacyjnej, podniesienia wydajności pracy kobiet w różnych sektorach zawodowych, wyróżniania i nagradzania przodownic pracy"51.

47 AAN, PZPR, KC, KWB, 237/XV-9, Sprawozdanie dotyczace pracy przodownic społecznych wojew. białostockiego, k. 58-60.

48 Ibidem, k. 62-67.

49 M. Wawrykowa, Udziat Ligi Kobiet w dyskusji nad Projektem Konstytucji, „Nasza Praca” 1952, nr 2, 8 .

50 Wstepna analiza pracy Ligi Kobiet w okresie 10-lecia jej istnienia, „Nasza Praca” 1956, nr 1, s. 5.

51 Ibidem. 


\section{DZIAŁALNOŚĆ ORGANIZACJI W DRUGIEJ POŁOWIE LAT PIĘĆDZIESIĄTYCH I W POCZĄTKACH LAT SZEŚĆDZIESIĄTYCH}

Od 1956 roku zmieniał się stosunek władz do roli i postrzegania miejsca kobiet w społeczeństwie polskim. Promowana w czasie stalinizmu produktywizacja została zastąpiona upowszechnianiem idei ,powrotu” kobiet do domu. Na planie pierwszym w życiu kobiet miała znajdować się dbałość o rodzinę i wychowanie dzieci oraz szeroko rozumiane kwestie dotyczące gospodarstwa domowego i jego unowocześniania. Zajęcia domowe i rodzinne miały być nadrzędne w życiu kobiety, praca zawodowa zaś - pozostawać drugoplanową. W 1956 roku reaktywowano zlikwidowane w 1953 koła zakładowe LK, które miały wspierać kobiety w ich codziennych problemach, przede wszystkim pomagać zatrudnionym w pogodzeniu dwóch przestrzeni ich aktywności: zawodowej i domowej ${ }^{52}$. Powołana w 1955 roku Krajowa Rada Matek miała wykazać, że matki polskie mają często trudności w wychowaniu swoich dzieci i potrzebują wsparcia w tym zakresie. W związku z tym LK miała angażować się w prowadzenie poradni dla kobiet i dzieci, współdziałać z sądami dla nieletnich w celu rozwiązywania problemów wychowawczych z dziećmi ${ }^{53}$. Zadania organizacyjne Ligi Kobiet miały wynikać z wytycznych przekazywanych podczas plenum KC PZPR ${ }^{54}$.

Na łamach biuletynu „Nasza Praca” w czerwcu 1956 roku, w ramach przygotowań do II Kongresu Ligi Kobiet 1957 roku, głos zabrały członkinie Ligi reprezentujące oddziały wojewódzkie. Wskazywały na popełniane błędy w działalności organizacji, dotyczące zwłaszcza ,zmniejszonego zainteresowania sprawami kobiet pracujących”. Jedna z przedstawicielek ZW LK w Poznaniu, krytykując „wyjście” LK z zakładów pracy, przekonywała słuchaczki, iż „,kobiety są rozgoryczone, że za wcześnie wyszły z zakładów pracy, wtedy gdy stanęła sprawa awansu i kwalifikacji kobiet" ${ }^{55}$. Podkreślała dalej, że mimo iż organizacja „nie pójdzie z powrotem do zakładów pracy należy stworzyć w zarządach LK sekcje ludzi odpowiedzialnych za pracę z kobietami pracującymi zawodowo" ${ }^{56}$. W dalszej części sprawozdania ze spotkania informowano czytelniczki o kryzysie w aktywności organizacji powodowanym brakiem wiary w skuteczność działań Ligi, w których nie kładzie się należytego nacisku na prawdziwe problemy, z jakimi borykają się kobiety w życiu codziennym. Jedna z uczestniczek pytała retorycznie:

czy w dalszym ciągu mamy rozmieniać naszą działalność na drobne i za swój podstawowy obowiązek uważać „włączanie się” do wszelkich akcji, pomijając nasze problemy? Czy fala

52 Zob. i por. M. Fidelis, Kobiety, komunizm i industrializacja w powojennej Polsce, Warszawa 2015, s. 235-236.

53 Wstęna analiza pracy Ligi Kobiet..., s. 7.

54 Na łamach biuletynu „Nasza Praca” publikowano tego rodzaju wskazania dla kierunków działań Ligi Kobiet, np. Zadania Ligi Kobiet w pracy wśród kobiet wiejskich w świetle wskazań IV Plenum KC PZPR, „Nasza Praca” 1956, nr 1, s. 8 i nast.

55 Mówią działaczki wojewódzkie Ligi Kobiet, „Nasza Praca” 1956, nr 6, s. 5.

56 Ibidem. 
pism płynąca z Zarządu Głównego z apelem „włączać się” nie wytworzyła w Zarządach Wojewódzkich pewnej rutyny, zobojętnienia, czy nie zasłoniła tych głównych spraw, wyłaniających się z życia kobiet? ${ }^{57}$

LK miała skupiać się na wsparciu członkiń i kobiet niezrzeszonych w rozwiązywaniu ich problemów, z jakimi borykały się na co dzień. Wsparcie Ligi miało wynikać z płynących do organizacji oddolnych potrzeb różnych środowisk kobiecych. W artykule opublikowanym w „Naszej Pracy” zatytułowanym Bliżej codziennego życia kobiety przedstawiono problem kobiet zwalnianych z pracy. Uzasadniano, zgodnie z ówczesną linią polityki państwa, że „praca kobiet w przemyśle ciężkim, zwłaszcza w niektórych gałęziach górnictwa i hutnictwa, nie jest wskazana ze względu na strukturę fizyczną kobiet i funkcje matek". Podkreślano, że poza tym wykonywanie tzw. zawodów męskich zapewniało wprawdzie wyższe płace niż w innych sektorach gospodarki, w których pracowały kobiety, ale nie zapewniało awansu społecznego. Tłumaczono czytelniczkom, że we wcześniejszym okresie sytuacja w zakresie zatrudnienia kobiet w zawodach męskich była odmienna, ponieważ

to życie nakazywało sięgać po rezerwę kobiecą. Trzeba było szybko odbudowywać przemysł, zwiększać wydobycie węgla, budować maszyny. Żywiołowość w realizowaniu zasady „kobiety do nowych zawodów" spowodowała, że dziś wiele kobiet zatrudnionych w górnictwie czy hutnictwie traci swój zawód w którym zdobyły kwalifikacje ${ }^{58}$.

Zapowiedzi zmian w działalności organizacyjnej Ligi przedstawiono podczas VIII Plenum KC PZPR w październiku 1956 roku. Szczególną rolę przypisywano pracy zarządów wojewódzkich i powiatowych w rozwiązywaniu problemów kobiet na poziomie lokalnym, między innymi w zakresie łączenia pracy zawodowej kobiet $\mathrm{z}$ ich obowiązkami rodzinnymi oraz udzielania wsparcia matkom, które zgłaszały problemy dotyczące wychowania dzieci. Podczas zjazdu A. Musiałowa podkreślała w swoim wystąpieniu, że w rozwiązywaniu problemów kobiet z poszczególnych regionów pomocna byłaby pewnego rodzaju samodzielność podejmowania inicjatyw, właśnie przez zarządy wojewódzkie i powiatowe $\mathrm{LK}^{59}$.

II Krajowy Zjazd Ligi Kobiet obradował w lipcu 1957 roku. Alicja Musiałowa w przedstawionym podczas zjazdu referacie poddała krytyce model działalności Ligi z okresu wcześniejszego. Uważała, że małą uwagę przypisywano właśnie rozwiązywaniu problemów codziennego, rodzinnego życia kobiet. Podkreślała, że LK dotychczas była mało konsekwentna w stawianiu konkretnych postulatów kierowanych do władz, a dotyczących wsparcia partii i rządu dla rozwiązywania konkretnych potrzeb kobiet. Podczas zjazdu podjęto uchwałę, w której uznano, że odtąd LK ,powinna nieustannie pracować nad podniesieniem kultury życia rodzinnego i społecznego, stawać w obronie trwałości rodziny”, również wspierać zatrudnienie kobiet w sektorze spółdzielczym i chałupniczym oraz rozwój żłobków, przedszkoli,

57 Ibidem, s. 4.

58 Bliżej codziennego życia kobiety, „Nasza Praca” 1956, nr 7/8, s. 1.

59 Codzienne sprawy kobiet to treść dalszej pracy naszej organizacji. Skrót przemówienia przewodniczacej ZG LK - Alicji Musiałowej na Plenum Zarządu Głównego Ligi Kobiet w dniu 30.X.1956 r. (ze stenogramu), „Nasza Praca” 1956, nr 11-12, s. 4-7. 
poradni świadomego macierzyństwa ${ }^{60}$. Podczas zjazdu uchwalono także nowy statut, w którym zaakcentowano potrzebę powstawania kół lokalnych, odpowiedzialnych za rozwiązywanie konkretnych postulatów, płynących z potrzeb środowisk kobiecych $\mathrm{z}$ poziomu miasta, gminy, osiedla ${ }^{61}$.

W roku 1959 kluczowe zadania w pracy LK ,na co dzień” prezentowało „Zwierciadło". Wskazywano na sprawy zatrudnienia kobiet, opieki nad dziećmi, pomocy kobietom w prowadzeniu gospodarstwa domowego, konieczności upowszechniania wśród kobiet zasad świadomego macierzyństwa, inicjowania przez Ligę pracy organizacyjnej również wśród kobiet wiejskich. Informowano czytelniczki, że podstawowe założenia działalności Ligi z roku 1958, dotyczące kierunków aktywności organizacji z hasłem „bliżej kobiety, rodziny i dziecka”, będą kontynuowane w roku następnym. Szczególny nacisk miała położyć Liga na przekonywanie kobiet do podejmowania przez nie zajęć chałupniczych, w okolicznościach licznie występujących zwolnień kobiet $\mathrm{z}$ ich dotychczasowych zakładów pracy. Ponadto w zakresie szeroko pojętej pomocniczości dla kobiet organizacja zapowiadała dalszą współpracę między innymi z Komitetem ds. Gospodarstwa Domowego oraz Towarzystwem Świadomego Macierzyństwa ${ }^{62}$.

Na terenie województwa białostockiego, zgodnie z wytycznymi Zarządu Głównego LK formułowanymi już przed II Krajowym Zjazdem Ligi ${ }^{63}$ oraz podczas zjaz$\mathrm{du}$, główny nacisk w działalności organizacji został położony na propagowanie modernizacji gospodarstw domowych, poradnictwo dla kobiet w zakresie prawnym i rodzinnym oraz opiekę nad dziećmi. Według ustaleń I. Ratman-Liwerskiej „ogółem w województwie udzielono w 1958 roku 2000 porad. Przodowała w nich Łomża, która po raz pierwszy zorganizowała porady lekarskie dotyczące świadomego macierzyństwa" ${ }^{\circ 4}$. W tym roku powstał także, zainicjowany przez Zarząd Wojewódzki LK, ośrodek gospodarstwa domowego o regionalnym zasięgu. W ramach działalności ośrodka członkinie Ligi propagowały wśród kobiet miast i wsi zwłaszcza „nowoczesne sposoby żywienia poprzez odczyty, pogadanki, kolportaż fachowej literatury, organizowanie kursów i pokazów"65. Od lat 60. szczególną uwagę skupiała Liga na pracy zapowiadanej już w II połowie lat 50., dotyczącej zainteresowań organizacji codziennymi sprawami kobiet. Efekty tej pracy miało przynieść szczególne zaangażowanie organizacji w miastach i osiedlach miejskich. Na plan dalszy odeszła praca w wiejskich środowiskach kobiecych. Główny nacisk kładła wówczas Liga na powstawanie nowych kół i rozwijanie już istniejących właśnie na terenie bezpośredniego zamieszkania kobiet.

60 M. Musiałowa, Referat przewodniczacej ZG LK Alicji Musiałowej wygłoszony na II Zjeździe LK [w:] Materiaty II Zjazdu LK w dniach 11-13 lipca 1957 r., Warszawa 1957, s. 3-28.

${ }_{61}$ Zob. D. Jarosz, op. cit., s. 328-329.

62 J.J., Zadania na co dzień, „Zwierciadło” 1959, nr 7, s. 3; W. Tycner, Demografia i zawód, „Zwierciadło" 1959, nr 7, s. 3.

63 Bliżej codziennego życia kobiety, „Nasza Praca” 1956, nr 7/8, s. 5.

64 I. Ratman-Liwerska, op. cit., s. 130.

${ }_{65}$ Ibidem, s. 130. Interesujące rozważania upowszechniania przez LK nowoczesnych form gospodarstwa domowego - B. Nowak, op. cit., s. 162-171 i nast. 


\section{AKTYWNOŚĆ LIGI KOBIET OD DRUGIEJ POŁOWY LAT SZEŚĆDZIESIĄTYCH DO 1975 ROKU}

Sprawozdanie z działalności LK za lata 1966-1970 zawiera informacje na temat aktywności organizacji w zakresie pracy ideowo-wychowawczej oraz pomocy udzielanej przez organizację kobietom, dotyczącej ich rozwoju zawodowego, a także przygotowania do życia w rodzinie i wychowania młodego pokolenia ${ }^{66}$. W przywołanym okresie na obszarze całego kraju inicjowano cykle konferencji oświatowo-wychowawczych pod hasłami „Zdrowie i kultura - podstawą współczesnej rodziny”, „Książka pomocna w wychowaniu dziecka” czy „Kultura i wychowanie”. Cenną w opinii LK formą pracy oświatowo-wychowawczej było organizowanie przez Zarząd Wojewódzki LK w Białymstoku „szkoły obywatelskiego wychowania”, a przez Zarząd Łódzki - „studia wychowania obywatelskiego oraz wychowania estetycznego"67. Ważną rolę spełniać miały powstające kluby i świetlice LK, które „były miejscem żywych dyskusji na temat małżeństwa i rodziny, stosunków wzajemnych dzieci i rodziców, obowiązków poszczególnych członków rodziny w prowadzeniu gospodarstw domowych, w racjonalnym ustalaniu i realizowaniu budżetu rodzinnego" 68 , oraz poradnie wychowawcze dla dzieci i młodzieży, w których pomocą kobietom służyły zespoły specjalistów: lekarzy, pedagogów, psychologów oraz prawników. Na szczególne wyróżnienie na tle kraju zasługiwały poradnie w Szczecinie i Białymstoku ${ }^{69}$. W ramach prac Zarządów Wojewódzkich LK we współpracy z Zakładami Doskonalenia Zawodowego prowadzono kursy doskonalenia zawodowego dla kobiet pracujących ${ }^{70}$.

Od 1966 roku w wyniku uchwały KC PZPR rolę przewodnią w rozwoju ruchu kobiecego odgrywać miały związki zawodowe, które w zamyśle władz partyjnych miałyby zastępować również działalność Ligi Kobiet w zakładach pracy. Od końca lat 60. zwiększał się z kolei odsetek kobiet wśród przewodniczących rad zakładowych oraz w tzw. aktywie społecznym związków zawodowych ${ }^{71}$. Sytuacja spowodowała bardzo poważne zmniejszenie liczby członkiń Ligi, zwłaszcza wśród kobiet pracujących. Przykładowo przewodnicząca Zarządu Wojewódzkiego Ligi Kobiet w Warszawie informowała, że w 1966 roku liczba członkiń w organizacji warszawskiej zmniejszyła się z 80000 do $4600^{72}$. W II połowie lat 60 , po opuszczeniu przez Ligę Kobiet zakładów pracy, organizacja zaangażowała się między innymi w two-

66 Sprawozdanie z działalności Ligi Kobiet za lata 1966-70, Warszawa 1970, s. 4 i nast., 30 i nast.

67 Ibidem, s. 6-7.

68 Ibidem, s. 25.

69 Ibidem, s. 41.

70 Ibidem, s. 55.

71 W 1971 r. kobiety stanowić miały $35 \%$ składu osobowego rad zakładowych oraz $25 \%$ przewodniczących rad zakładowych - Materiały z V Krajowego Zjazdu Ligi Kobiet. Dyskusja. Irena SroczyńskaSekretarz CRZZ, wiceprzewodniczaca Krajowej Rady Kobiet Polskich, „Nasza Praca” 1971, nr 10-11, s. 31.

72 Materiały z V Krajowego Zjazdu Ligi Kobiet. Dyskusja. Wiktoria Różańska - Poset na Sejm, przewodniczaca ZWLK wojew. warszawskiego..., s. 49. 
rzenie kół rodzin milicyjnych, które miałyby ściśle z nią współpracować, zwłaszcza w pracy propagandowej. Zasady działania kół milicyjnych miały być spójne z celami statutowymi Ligi oraz uchwałami Zarządu Głównego $\mathrm{LK}^{73}$.

W 1967 roku Liga Kobiet uchwaliła nowy statut, w którym wskazała jednoznacznie, że obszarem jej działania pozostają miasta i osiedla miejskie. Wśród celów organizacji wskazano na istotę pracy polityczno-propagandowej, zwłaszcza w środowiskach kobiecych, umacnianie pozycji kobiety w społeczeństwie i rodzinie, organizację poradnictwa zawodowego dla kobiet oraz powoływanie inicjatyw z zakresu opieki społecznej. Informowano również w dokumencie o konieczności rozwoju intensywnej współpracy z Komitetami Gospodarstwa Domowego, upowszechniania $\mathrm{w}$ społeczeństwie znaczenia godzenia życia rodzinnego kobiet $\mathrm{z}$ ich pracą zawodową ${ }^{74}$.

W ramach działalności kół miejskich i blokowych w województwie białostockim w latach 60. liderki LK starały się promować wśród kobiet takie obszary zajęć, które byłyby przydatne w ich życiu codziennym. Organizowano w związku z tym w ramach współdziałania z Komitetami Gospodarstwa Domowego pokazy kulinarne, uczono słuchaczki nowoczesnych zasad prowadzenia domu, w tym podawania posiłków i przyjmowania gości. Za istotne uznawano podejmowanie zagadnień dotyczących wychowania dzieci i pielęgnowania niemowląt. Szczególnie cenione przez matki były zajęcia będące również formami spędzania czasu wolnego dzieci $^{75}$. W klubach LK wygłaszano prelekcje na temat prawa, pedagogiki, zdrowia, oświaty sanitarnej, kultury życia codziennego, higieny oraz metod nowoczesnego urządzania domów i prowadzenia gospodarstwa domowego ${ }^{76}$. Na oddzielne podkreślenie zasługiwały prowadzone przez LK poradnie prawne. Dla przykładu w 1968 roku poradnie prawno-społeczne i wychowania udzieliły na terenie województwa białostockiego 2000 porad, w tym 548 alimentacyjnych, 157 rozwodowych, 225 dotyczących zatrudnienia, 157 - łagodzenia konfliktów rodzinnych, 227 - wychowania dzieci. W poradniach pomagano także w pisaniu pozwów alimentacyjnych. Taką usługę zaoferowano 293 kobietom $^{77}$. W latach 60. liczba kół LK w województwie

73 Zob. A. Marcinkiewicz-Kaczmarczyk, Koła Rodzin Milicyjnych - powstanie, organizacja i praca propagandowa „Czasopismo Naukowe Instytutu Studiów Kobiecych” 2017, nr 1(2), s. 33-34.

74 AIPN, BU 1585/19737, Statut Ligi Kobiet, Warszawa 1967, k. 2, 6-9. Na temat działalności polityczno-propagandowej Ligi Kobiet po 1967 r. zob. A. Marcinkiewicz-Kaczmarczyk, Rola Ligi Kobiet w popularyzowaniu polityki wladz „Polski Ludowej” [w:] „Polska Ludowa” 1944-1989 - wybrane problemy historii politycznej i społecznej, red. D. Litwin-Lewandowska, K. Bałękowski, Lublin 2016, s. 295 i nast.

75 E. Świętochowska, Sytuacja społeczna kobiet w PRL w latach 1956-1970 na przykładzie województwa białostockiego [w:] „,Mała stabilizacja” w województwie biatostockim 1956-1970, red. M. Markiewicz, Białystok 2012, s. 204.

76 APB, Komitet Wojewódzki Polskiej Zjednoczonej Partii Robotniczej w Białymstoku (dalej: KW PZPR), Wydział Organizacyjny Komitetu Wojewódzkiego (WO KW), Materiały dot. działalności LK w woj. białostockim 1969 - V 1975 (MLK woj. biał.), 1131, Uchwała VI Wojewódzkiej Konferencji sprawozdawczo-wyborczej obradujacej w dniu 12 maja 1970 r., k. 86.

77 APB, KW PZPR, WO KW, MLK woj. biał., 1131, Informacja dotyczaca stopnia realizacji uchwat partyjnych $i$ resortowych $w$ sprawie pracy $z$ kobietami, $\mathrm{k} .101$. 
białostockim miała oscylować w granicach od około 200 do ponad 300, liczba członkiń również szybko wzrastała - utrzymywała się w granicach 4300 w 1966 roku i $7700 \mathrm{w} 1969 \mathrm{roku}^{78}$.

Zaangażowanie poświęcała LK również intensywnej pracy propagandowej. Na przykład w 1969 roku, w związku z przygotowaniami do V Zjazdu PZPR oraz wyborów do Sejmu i rad narodowych, zarządy wojewódzkie i zarządy miejskie LK:

pracę na odcinku poziomu ideowego kobiet zarówno pracujących jak i niepracujących prowadziły poprzez organizację szeregu spotkań z działaczami politycznymi, gospodarczymi, radnymi, oficerami LWP itp. Na spotkaniach tych zapoznawano kobiety z sytuacją międzynarodową, z podstawowymi osiągnięciami kraju, województwa i powiatu,

- podano w informacji dotyczącej stopnia realizacji uchwał partyjnych w sprawie pracy z kobietami, w tym realizacji tych uchwał przez ZW LK województwa białostockiego. W tym też roku w Łomży i Ełku zorganizowano Szkoły Obywatelskiego Wychowania, a w programie znalazła się tematyka dotycząca zagadnień kultury, wiedzy politycznej, ekonomicznej, zasad prawnych. Do tych szkół uczęszczało wówczas 50-60 kobiet, mieszkanek tych miast ${ }^{79}$. Należy dodać, że w województwie działalność prowadziły w tym czasie 302 koła LK, do których należało 7767 członkiń ${ }^{80}$.

Od początku lat 70. w dyskursie propagandowym LK występowała tematyka dotycząca Międzynarodowego Roku Kobiet, przypadającego w 1975 roku. W celu nadania odpowiednej rangi wydarzeniom związanym z Rokiem Kobiet Rada Ministrów PRL podjęła w sierpniu 1974 roku uchwałę, w której nakreślono obowiązki organizacji społecznych w zakresie „różnorodnych działań zmierzających do polepszenia warunków życia i pracy kobiet, a w konsekwencji do podniesienia na jeszcze wyższy poziom ich pozycji społeczno-zawodowej i rodzinnej”. Wszelkie akcje społeczne podejmowane na rzecz środowisk kobiecych i organizowane przez Ligę w osiedlach i miastach oraz inne inicjatywy szczebla lokalnego, w tym kursy, pokazy, akcje oświatowe, inicjatywy wydawnicze organizowane i inicjowane przez Ligę, miały być podniosłe i uroczyste w czasie obchodów w 1975 roku Międzynarodowego Roku Kobiet ${ }^{81}$.

W 1974 roku ogłoszono kierunki działalności Ligi Kobiet na terenie województwa białostockiego z tytułu obchodów trzydziestolecia Polski Ludowej. Zarząd Wojewódzki LK w celu uczczenia „trzydziestolecia PRL” proponował ,jak największe podjęcie czynu obywatelskiego pod nazwą «Rodzina swojemu osiedlu», ogłoszonego przez ZG LK i «Przyjaciółkę» jak również uczestnictwo w powszechnym czynie społecznym mieszkańców miast w zakresie porządkowania i upiększania miast i osiedli"»2. Ponadto członkinie Ligi miały uczestniczyć w zbiórce funduszy na pomnik poległych w II wojnie światowej bohaterów ziemi białostockiej oraz

78 Ibidem, k. 91 - 92; por. I. Ratman-Liwerska, op. cit., s. 149 (podaje dane zawyżone).

79 Ibidem, k. 97-105.

80 Ibidem, k. 97.

81 Zarząd Główny Ligi Kobiet, Program działania Ligi Kobiet w Międzynarodowym Roku Kobiet, „Nasza Praca” 1975, nr 1-2, s. 9-17.

${ }^{82}$ APB, KW PZPR, WO KW, MLK woj. biał., 1131, Materialy dotyczace LK w woj. bialostockim, Kierunki działalności Ligi Kobiet woj. białostockiego w obchodach XXX-lecia PRL, k. 225. 
działalności propagandowej dotyczącej popularyzacji „dorobku socjalistycznego” w regionie i na obszarze kraju ${ }^{83}$.

Rok 1975, ogłoszony Międzynarodowym Rokiem Kobiet, miał również szczególne znaczenie $\mathrm{z}$ tytułu obchodów trzydziestoletniej działalności organizacji ligowej. O osiągnięciach LK w okresie do 1975 roku przypominały władze Komitetu Wojewódzkiego PZPR. Za cenne uznawano w szczególności „sprzężenie pracy kół z komitetami osiedlowymi i domowymi”. Do ważnych aspektów zaliczano także zaangażowanie członkiń Ligi w kwestie rozwoju oświaty, kształtowanie kultury czasu wolnego kobiet i ich rodzin. Zwracano też uwagę na konieczność dostosowania zaangażowania ruchu ligowego do specyfiki obszaru działalności, to jest „środowisk kobiet pracujących i niepracujących zawodowo, poza zakładem pracy i w miejscu ich zamieszkania" ${ }^{44}$.

W wytycznych PZPR w sprawie obchodów Międzynarodowego Roku Kobiet zawarto nawiązanie do uchwał VI Zjazdu PZPR z grudnia 1971 roku. W podjętych uchwałach VI Zjazdu wskazywano na kierunki rozwoju Polski Ludowej i prac nad „odnową wszystkich dziedzin życia społeczeństwa polskiego". W zadaniach na rok 1975 wyznaczanych przez Egzekutywę KW PZPR w Białymstoku nawiązywano do treści uchwał Zjazdu PZPR z 1971 roku, gdzie za istotne uznano podjęte wówczas zagadnienia „kształtowania i umacniania rodziny, ochrony macierzyństwa i zdrowia kobiety, rozszerzenie opieki nad dzieckiem, podnoszenia pozycji zawodowej i społecznej oraz poprawy warunków życia i pracy kobiet" ${ }^{85}$. Nawiązywano również do osiągnięć w kwestii wprowadzenia w ostatnim okresie korzystnych zmian prawnych w kwestii kobiecej, to jest płatnych urlopów macierzyńskich (trwających od 26 do 39 tygodni), trzyletnich urlopów wychowawczych, powołanie „banku alimentacyjnego" i zwiększenia zasiłków rodzinnych na dzieci szczególnej troski. Obchody Międzynarodowego Roku Kobiet miały być okazją do zaakcentowania wkładu kobiet w rozwój Polski Ludowej ${ }^{86}$.

Wojewoda białostocki ogłosił plan działań w związku z Międzynarodowym Rokiem Kobiet. Plan był wynikiem wcześniejszego rozporządzenia wojewody z 1974 roku w związku z postanowieniami wymienianej uchwały Rady Ministrów nr 182/74 z 1 sierpnia 1974 roku. Zgodnie z założeniami planu wojewoda nakazał dyrektorom wydziałów Urzędu Wojewódzkiego, naczelnikom powiatów, prezydentowi Miasta Białegostoku oraz przedstawicielstwu organizacji zawodowych i społecznych sporządzenie strategii działania w związku z planowanymi obchodami ${ }^{87}$. Programy strategii uwzględniać miały zasady awansowania kobiet w pracy zawodowej oraz formy pomocy socjalnej udzielane kobietom i ich rodzinom. Zadania wynikające z niniejszego

83 Ibidem.

${ }^{84}$ Ibidem, k. 235-238.

${ }^{85}$ APB, KW PZPR, WO KW, Informacje dotyczące działalności partii wśród kobiet i ruchu kobiecego, 1136, Wytyczne Egzekutywy KW PZPR w Białymstoku w sprawie obchodów Międzynarodowego Roku Kobiet, k. 24.

${ }^{86}$ Ibidem, k. 25.

${ }^{87}$ APB, KW PZPR, WO KW, Informacje dotyczące działalności partii wśród kobiet i ruchu kobiecego, 1136, Ramowy program dziatania w obchodach Międzynarodowego Roku Kobiet, k. 47-50. 
programu wpisywać się miały w ogólny plan rozwoju społeczno-gospodarczego województwa na rok 1975 i plan programu na lata 1976-1980. Szczególnie podniosły i uroczysty charakter w roku obchodów miały mieć uroczystości związane z Międzynarodowym Dniem Kobiet, obchodzonym 8 marca. Popularyzacji tych wydarzeń służyć miały między innymi cyklicznie zamieszczone w prasie, w „Gazecie Białostockiej” i „Kontrastach”, oraz prezentowane w Polskim Radiu Białystok przekazy upowszechniające dokonania kobiet, analizowane z perspektywy trzydziestolecia Polski Ludowej ${ }^{88}$.

Liga Kobiet na terenie województwa białostockiego wskazała konkretne kierunki działań zaplanowanych na rok 1975 . Za cel priorytetowy uznano popularyzowanie dotychczasowych dokonań organizacji dotyczących działań na rzecz kobiet oraz wyznaczonych kierunków dalszego rozwoju organizacyjnego Ligi w województwie białostockim ${ }^{89}$. Szczególną aktywność w zakresie podejmowania różnorodnych inicjatyw związanych z 1975 rokiem wykazały komitety miejskie LK. Należy dodać, że w 1975 roku liczba kół miejskich w województwie białostockim wynosiła 149, zrzeszonych było w nich blisko 4700 kobiet. W sprawozdaniu Zarządu Wojewódzkiego LK za rok 1975 ujęto szereg działań Ligi związanych z obchodami, między innymi w zakresie organizacji pomocy opiekuńczej dzieciom, udzielania porad prawnych kobietom czy pracy kulturalno-oświatowej w środowiskach kobiecych ${ }^{90}$. Ocena aktywności Ligi podczas obchodów miała odbyć się w I kwartale 1976 roku, dokonana przez gminne i powiatowe komitety Frontu Jedności Narodowej. Kompleksową ocenę wydarzeń roku obchodów planowano przedstawić podczas obrad plenarnego posiedzenia Wojewódzkiego Komitetu Frontu Jedności Narodowej w dniu 8 marca, co z kolei wiązać się miało z uczczeniem Międzynarodowego Dnia Kobiet ${ }^{91}$.

\section{PODSUMOWANIE}

SOLK w założeniu miała być organizacją apolityczną, jednak od samego począt$\mathrm{ku}$ swojego funkcjonowania związana była $\mathrm{z}$ aparatem komunistycznym, również poprzez członkostwo liderek organizacji w PPR i później PZPR, i czynnie wspierała budowanie ładu komunistycznego w Polsce Ludowej. Była to organizacja, która przez cały okres swojego istnienia realizowała program wynikający z wytycznych

${ }^{88}$ Ibidem, k. 51-56 i nast.

${ }^{89}$ APB, KW PZPR, WO KW, Informacje dotyczące działalności partii wśród kobiet i ruchu kobiecego, 1136, Główne kierunki działania Ligi Kobiet w województwie białostockim w 1975 r., k. 123 i nast.

${ }^{90} \mathrm{APB}, \mathrm{KW}$ PZPR, WO KW, Informacje dotyczące działalności partii wśród kobiet i ruchu kobiecego, 1136, Sprawozdanie Zarządu Glównego Ligi Kobiet w Białymstoku za 1975 rok, k. 136-158.

${ }_{91}$ APB, KW PZPR, WO KW, Informacje dotyczące działalności partii wśród kobiet i ruchu kobiecego, 1136, Wytyczne Egzekutywy KW PZPR w Biatymstoku w sprawie obchodów Międzynarodowego Roku Kobiet, k. 31; szerzej na temat obchodów Międzynarodowego Roku Kobiet - zob. M. Dajnowicz, Obchody Międzynarodowego Roku Kobiet..., s. 15-25. 
Komitetu Centralnego PPR i następnie PZPR. W pierwszych latach działalność, zwłaszcza SOLK, była jednak słabo ugruntowana, a same liderki poza pracą propagandową skupiały się głównie na budowaniu struktur i powiększaniu liczebności członkiń organizacji. Przez cały okres jednym z priorytetów stawianych przez Ligę było budowanie jej masowości i przez to wpływów w różnych kobiecych grupach społecznych, zawodowych i środowiskowych. Od 1949 roku, pod zmienioną nazwą - już jako LK, organizacja prowadziła działalność propagandowo-wychowawczą również w zakładach pracy, także wśród kobiecych środowisk robotniczych i w środowisku wiejskim. W okresie stalinizacji, w latach 1949-1953, Liga włączyła się w promowanie pracy kobiet w sektorze tzw. zawodów męskich, między innymi w przemyśle, a nawet $\mathrm{w}$ górnictwie. Upowszechniano wówczas aktywność zawodową kobiet zwłaszcza w produkcji. Wiązać się to miało w krzewionym także wśród kobiet dyskursie propagandowym z propagowaniem równouprawnienia kobiet z mężczyznami, co podkreślały choćby zapisy statutu organizacji z 1951 roku. Krytyka działalności LK, która doprowadzić miała w założeniu jej liderek do odnowy struktur organizacji, następowała od 1950 roku. LK podjęła wówczas próby pozyskania również kobiet niepracujących, gospodyń domowych.

Odejście od realizacji programu produktywizacji około 1956 roku wiązało się ze zwalnianiem kobiet z pracy i propagowaniem - w co włączyła się również LK wzorca kobiety głównie jako opiekunki rodziny, odpowiedzialnej za wychowanie dzieci. W programie propagandowym LK zaczęła eksponować, wyraźniej niż wcześniej, konieczność włączania się organizacji w rozwiązywanie codziennych problemów kobiet polskich, wynikających z łączenia życia prywatnego z zawodowym oraz inicjatywy powodujące usprawnienie życia domowego kobiet. Od początków lat 60 . z jednej strony szczególny nacisk kładła Liga na tworzenie struktur poziomu lokalnego i pracę propagandowo-wychowawczą $w$ miejscu zamieszkania kobiet, $z$ drugiej zaś w przekazie kierowanym do kobiet uzasadniała ich możliwości dotyczące godzenia pracy zawodowej z obowiązkami wychowawczymi i rodzinnymi.

Przełomowe okazały się lata 1966 i 1967, kiedy to Liga Kobiet w 1966 roku, po „opuszczeniu zakładów pracy”, zaczęła angażować się w większe niż wcześniej umacnianie wpływów w osiedlach miejskich czy klubach osiedlowych, także współtworząc zdominowane przez organizację struktury, między innymi w milicji (KRM). Zgodnie ze statutem z 1967 roku głównym celem organizacji pozostawała praca propagandowa, wynikająca $z$ wytycznych KC PZPR, oraz tzw. użytkowa w miastach, organizująca różnorodną pomoc kobietom, przez co mająca przynieść realne rezultaty wpływów Ligi w środowiskach kobiet pracujących i gospodyń domowych. Służyć miały temu powoływane przez Ligę zwłaszcza koła blokowe, różnego rodzaju poradnie prawne, wychowawcze i pomocy socjalnej, funkcjonujące na przykład przy klubach osiedlowych w miastach.

Obchody Międzynarodowego Roku Kobiet w 1975 roku i działania inicjowane przez władze związane $\mathrm{z}$ obchodami, podejmowane od początku lat 70., wpisywały się $\mathrm{w}$ katalog działań propagandowych kierowanych do kobiet, określonych już w drugiej połowie lat 60. Liga włączała się w całokształt działań związanych $\mathrm{z}$ obchodami, co z kolei wpływać miało na wzmocnienie autorytetu organizacji oraz 
promowanie dorobku LK i PZPR na różnych polach, ujmowanego w perspektywie jej trzydziestoletniej działalności.

\section{BIBLIOGRAFIA}

\section{Dokumenty archiwalne}

AAN, SOLK, 1, Deklaracja ideowa Społeczno-Obywatelskiej Ligi Kobiet, k. 8-10.

AAN, SOLK, 1, Regulamin dla Zarządu Głównego Społeczno-Obywatelskiej Ligi Kobiet, k. 11.

AAN, SOLK,1, S.O.L.K. w Katowicach. Poradnia prawna, k. 31, S.O.L.K. w Katowicach. Instrukcje organizacyjne, k. 32.

AAN, SOLK, 1, Zadania Wydziału Spółdzielczego w Kole Społeczno-Obywatelskiej Ligi Kobiet, k. 17, 20 i nast.

AAN, SOLK, 1, Zakres działania Wydziałów Zarzadu Głównego Społeczno-Obywatelskiej Ligi Kobiet, k. 12 i nast.

AAN, SOLK, 2, Protokół z posiedzenia Wydziału Spółdzielczego Społeczno-Obywatelskiej Ligi Kobiet, k. 9 i nast.

AAN, SOLK, 3, Sprawozdanie z działalności Społeczno-Obywatelskiej Ligi Kobiet. Koła przy Biurze Prezydialnym K. R. N., k. 1 i nast.

AAN, SOLK, 4, Sprawozdanie z działalności Wydziału Organizacyjnego i Wydziału Spótdzielczego w Zarządzie Wojewódzkim Społeczno-Obywatelskiej Ligi Kobiet na województwo gdańskie, k. 1-17, 26, 38.

AAN, SOLK, 5, Plan pracy Wydziału Spółdzielczego Wojewódzkiego Zarządu S.O.L.K. w Gdańsku za m-c sierpień 1947, k. 3.

AAN, PZPR, KC, KW, 237/XV-29, Instrukcja w sprawie obchodu 1-ego maja, k. 35.

AAN, PZPR, KC, WK KW, 237/XV-30, Osiagnnięcia i braki, k. 75-78, 79.

AAN, PZPR, KC, WK KW, 237/XV-30, Rozwój Ligi Kobiet w okresie od 1945-1951 r., k. 1, $3,4$.

AAN, PZPR, KC, WK KW, 237/XV-30, Sprawozdanie z działalności Ligi Kobiet za IV kwartat, 1951 r., k. 49.

AAN, AAN, PZPR, KC, WK, 237/XV-7, Sprawozdanie Orlowskiej Edwardy, k. 9-11.

AAN, PZPR, KC, WK KWB, 237/XV-9, Sprawozdanie Wydziatu Kobiecego K.W. P.Z.P.R. w Białymstoku za m-c kwiecień 1949 r., k. 30-31.

AAN, PZPR, KC, KWB, 237/XV-9, Sprawozdanie Wydziału Kobiecego przy K.W. P.Z.P.R. w Biatymstoku za miesiąc luty 1949 r., k. 22.

AAN, PZPR, KC, WK KWB, 237/XV-9, Sprawozdanie Wydziatu Kobiecego Komitetu Wojewódzkiego P.Z.P.R. w Białymstoku za m-c wrzesień 1949 r., k. 45, 46.

AAN, AAN, PZPR, KC, KWB, 237/XV-9, Sprawozdanie dotyczace pracy przodownic spotecznych wojew. białostockiego, k. 58-60.

AIPN, BU 01760/350, Materiaty dotyczace Zarzadu Ligi Kobiet przy MBP. Protokoly z zebrań, sprawozdania, notatki 1946-53, Protokół Ogólnego Zebrania Ligi Kobiet M. B. P. $w$ dniu 7 maja 1947 r., k. 4.

AIPN, BU 1585/19737, Statut Ligi Kobiet, Warszawa 1967, k. 2, 6-9. 
APB, KW PPR, 229, Sprawozdanie z 1I pracy Zarzadu SOLK za okres od do 30 IX 1946 r., k. 13 i nast.

APB, KW PPR, Sprawozdanie Zarzadu Wojewódzkiego SOLK w Białymstoku za miesiac grudzień 1947, k. 25.

APB, KW PPR, Sprawozdanie Wydziału Kobiecego KW PPR w Białymstoku za okres od marca do września 1948 r., k. 104.

APB, KW PZPR, WO KW, Informacje dotyczące działalności partii wśród kobiet i ruchu kobiecego, 1136, Główne kierunki działania Ligi Kobiet $w$ województwie białostockim w 1975 r., k. 123 i nast.

APB, KW PZPR, WO KW, Informacje dotyczące działalności partii wśród kobiet i ruchu kobiecego, 1136, Ramowy program działania w obchodach Międzynarodowego Roku Kobiet, k. 47-50.

APB, KW PZPR, WO KW, Informacje dotyczące działalności partii wśród kobiet i ruchu kobiecego, 1136, Sprawozdanie Zarządu Głównego Ligi Kobiet w Białymstoku za 1975 rok, k. 136-158.

APB, KW PZPR, WO KW, Informacje dotyczące działalności partii wśród kobiet i ruchu kobiecego, 1136, Wytyczne Egzekutywy KW PZPR w Bialymstoku w sprawie obchodów Międzynarodowego Roku Kobiet, k. 24, 25, 31.

APB, KW PZPR, WO KW, MLK woj. biał., 1131, Informacja dotyczaca stopnia realizacji uchwat partyjnych i resortowych $w$ sprawie pracy z kobietami, k. 91-92, 97, 101, 105.

APB, KW PZPR, WO KW, MLK woj. biał., 1131, Materiały dotyczace LK w woj. biatostockim, Kierunki działalności Ligi Kobiet woj. białostockiego w obchodach XXX-lecia PRL, k. 225, 235-238.

APB, KW PZPR, WO KW, MLK woj. biał., 1131, Uchwała VI Wojewódzkiej Konferencji sprawozdawczo-wyborczej obradujacej w dniu 12 maja 1970 r., k. 86.

\section{Dokumenty publikowane}

Musiałowa M., Referat przewodniczacej ZG LK Alicji Musiałowej wygłoszony na II Zjeździe LK [w:] Materiaty II Zjazdu LK w dniach 11-13 lipca 1957 r., Warszawa 1957.

Sprawozdanie z działalności Ligi Kobiet za lata 1966-70, Warszawa 1970.

Statut Spoleczno-Obywatelskiej Ligi Kobiet, [Warszawa], b.r.w.

\section{Artykuły prasowe}

Blizej codziennego życia kobiety, „Nasza Praca” 1956, nr 7/8.

Codzienne sprawy kobiet to treść dalszej pracy naszej organizacji. Skrót przemówienia przewodniczacej ZG LK - Alicji Musiałowej na Plenum Zarządu Głównego Ligi Kobiet w dniu 30 X 1956 r. (ze stenogramu), „Nasza Praca” 1956, nr 11-12.

Golsztyńska A., Analiza pracy świetlic, „Nasza Praca” 1951, nr 20.

J.J., Zadania na co dzień, „Zwierciadło” 1959, nr 7.

Liga Kobiet przy pracy, „Nasza Praca” 1947, nr 3-4.

Liga Kobiet przy pracy, „Nasza Praca” 1948, nr 3-4. 
Materiały z V Krajowego Zjazdu Ligi Kobiet. Dyskusja. Irena Sroczyńska - Sekretarz CRZZ, wiceprzewodniczaca Krajowej Rady Kobiet Polskich, „Nasza Praca” 1971, nr 10-11.

Materiały z V Krajowego Zjazdu Ligi Kobiet. Dyskusja. Wiktoria Różańska-Poseł na Sejm, przewodniczaca ZWLK wojew. warszawskiego, „Nasza Praca” 1971, nr 10-11.

Mówią działaczki wojewódzkie Ligi Kobiet, „Nasza Praca” 1956, nr 6.

Praca wśród kobiet wiejskich woj. lubelskiego, „Nasza Praca” 1951, nr 13-14.

Tycner W., Demografia i zawód, „Zwierciadło” 1959, nr 7.

Wawrykowa M., Udziat Ligi Kobiet $w$ dyskusji nad Projektem Konstytucji, „Nasza Praca” 1952 , nr 2.

Wawrykowa M., Wnioski i uwagi z wizytacji z terenu. Jeszcze raz o Suwałkach, „Nasza Praca" 1951, nr 15.

Wstępna analiza pracy Ligi Kobiet w okresie 10-lecia jej istnienia, „Nasza Praca” 1956, nr 1. s. 5.

Zarząd Główny Ligi Kobiet, Program działania Ligi Kobiet w Międzynarodowym Roku Kobiet, „Nasza Praca” 1975, nr 1-2.

\section{Monografie}

Fidelis M., Kobiety, komunizm i industrializacja w powojennej Polsce, Warszawa 2015.

Ratman-Liwerska I., Stowarzyszenie jako czynnik społeczno-wychowawczej aktywizacji kobiet (na przykładzie badań na Białostocczyźnie), Białystok 1984.

\section{Artykuły w pracach zbiorowych}

Dajnowicz M., Działalność Społeczno-Obywatelskiej Ligi Kobiet w świetle „Naszej Pracy” (1947-1949) [w:] Polityka i politycy w prasie XX i XXI wieku, pod red. M. Dajnowicz i A. Miodowskiego, Białystok 2016.

Jarosz D., Idee, programy i realia: funkcje Ligi Kobiet w porządku instytucjonalnym Polski Ludowej (1945-1957) [w:] Działaczki spoleczne, feministki, obywatelki. Samoorganizowanie się kobiet na ziemiach polskich po 1918 roku (na tle porównawczym), t. II, red. A. Janiak-Jasińska, K. Sierakowska, A. Szwarc, Warszawa 2009.

Jarska N., Liga Kobiet w terenie. Działalność Zarzadu Dzielnicowego Poznań-Wilda 19561966 [w:] Letnia Szkoła Historii Najnowszej 2009. Referaty, red. Ł. Kamiński, T. Kozłowski, Warszawa 2010.

Marcinkiewicz-Kaczmarczyk A., Rola Ligi Kobiet w popularyzowaniu polityki wtadz „Polski Ludowej” [w:] „Polska Ludowa” 1944-1989 - wybrane problemy historii politycznej i społecznej, red. D. Litwin-Lewandowska, K. Bałękowski, Lublin 2016.

Stasiewicz A., Działalność Społeczno-Obywatelskiej Ligi Kobiet w latach 1945-1948 na Białostocczyźnie w świetle dokumentów PPR [w:] Kobiety na zakręcie 1933-1989, red. E. Chabros, A. Klarman, Wrocław 2014.

Świętochowska E., Sytuacja społeczna kobiet w PRL w latach 1956-1970 na przyktadzie województwa białostockiego [w:] „Mała stabilizacja” w województwie białostockim 1956-1970, red. M. Markiewicz, Białystok 2012. 


\section{Artykuły w czasopismach naukowych}

Dajnowicz M., Obchody Międzynarodowego Roku Kobiet 1975 na Białostocczyźnie (na tle głównych kierunków działalności Ligi Kobiet w kraju i regionie), „Czasopismo Naukowe Instytutu Studiów Kobiecych" 2017, nr 1(2).

Dajnowicz M., „Zwierciadto” platforma polityczna Ligi Kobiet w okresie PRL (19571961, 1982-1989), „Rocznik Historii Prasy Polskiej” 2017, t. 20, z. 3(47).

Lubik-Reczek N., Reczek R., Liga Kobiet - organizacja ,reprezentujaca” interesy kobiet w Polsce Ludowej. Zarys działania, „Środkowoeuropejskie Studia Polityczne” 2013, nr 4.

Marcinkiewicz-Kaczmarczyk A., Koła Rodzin Milicyjnych - powstanie, organizacja i praca propagandowa, „Czasopismo Naukowe Instytutu Studiów Kobiecych” 2017, nr 1(2).

\section{Materiały internetowe}

Nowak B., Serving Women and the State: The League of Women in Communist Poland, praca doktorska, The Ohio State University 2004, s. 162-171 i nast. [dostęp: 7.04.2017]. Dostępny w World Wide Web: <http://bit.ly/2diMB3h>. 